\title{
WORKING WITH THE ENEMY: ALCOHOLIC BEVERAGE IN THE WORK CONTEXT
}

\author{
Trabalhando com o inimigo: a bebida alcoólica no contexto laboral \\ Trabajando con el enemigo: la bebida alcohólica en el contexto laboral \\ Silvio Éder Dias da Silva', Joel Lobato da Costa², Jeferson Santos Araújo ${ }^{3}$, Adriana Alaide Alves Moura ${ }^{4}$, Josielle \\ Silva Magalhães ${ }^{5}$ Natália Barros Menezes Cabral
}

\section{How to cite this circle:}

Silva SED, Costa JL, Araújo JS, Moura AAA, Magalhães JS, Cabral NBM. Working with the enemy: alcoholic beverage in the work context. 2020 jan/dez; 12:934-938. DOI: http://dx.doi.org/0.9789/2175-5361.rpcfo. v12.6319.

\begin{abstract}
Objective: To identify and analyze the social representations of the workers of a brewery about the work and effects of the alcoholic beverage in this relation. Methods: To reach this, a descriptive study was developed, with a qualitative approach that was based on the theory of social representations. Results: The work presents itself with a fundamental role in the life of individuals, contributing to the construction of their identity. The worker on the effect of the alcoholic beverage develops a diminished attention on its activities being susceptible to damages from work accidents, where the analysis of the employed content allowed to know that the alcoholic drink related to the work is objectified to several behaviors of occupational risks. Conclusion: The representations presented by the participants contribute directly to the nurses performing their care interventions to this population.
\end{abstract}

Descriptors: Nursing; Occupational health; Alcoholism.

\section{RESUMO}

Objetivo: Identificar e analisar as representações sociais dos trabalhadores de uma cervejaria sobre o trabalho e os efeitos da bebida alcoólica nesta relação. Métodos: Para alcance deste, desenvolveu-se um estudo descritivo, com abordagem qualitativa que foi fundamentado na teoria das representações sociais. Resultados: O trabalho apresenta-se com um papel fundamental na vida dos indivíduos, contribuindo para a construção da sua identidade. O trabalhador sobre efeito da bebida alcoólica desenvolve uma atenção diminuída sobre suas atividades estando susceptível a sofre danos de acidentes de trabalho, aonde a análise de conteúdo empregada permitiu conhecer que a bebida alcoólica relacionada ao trabalho está objetivada a vários comportamentos de riscos ocupacionais. Conclusão: As representações apresentadas pelos participantes contribuem diretamente para que o enfermeiro realize suas intervenções de cuidado a essa população. Descritores: Enfermagem; Saúde do trabalhador; Alcoolismo.

1 Nursing Graduate by the Universidade do Estado do Pará (UEPA), PhD in Nursing by the Universidade Federal de Santa Catarina (UFSC), Professor at Universidade Federal do Pará (UFPA).

2 Nursing Graduate by the UFPA.

3 Nursing Graduate by the UFPA, PhD in Nursing by the Universidade de São Paulo (USP).

4 Nursing Graduate by the UFPA.

5 Nursing Graduate by the UFPA.

6 Nursing Graduate by the UFPA. 


\section{RESUMEN}

Objetivo: Identificar y analizar las representaciones sociales de los empleados de una fábrica de cerveza en la mano de obra y los efectos del alcohol en esta relación. Métodos: Para llegar a esto, se desarrolló un estudio descriptivo con un enfoque cualitativo que se basa en la teoría de las representaciones sociales. Resultados: El artículo presenta un papel fundamental en la vida de las personas, contribuyendo a la construcción de su identidad. El trabajador en el efecto del alcohol se desarrolla una atención disminuida sobre sus actividades y es probable que sufran daños los accidentes de trabajo, donde el análisis de contenido empleada permitió conocer que el trabajo relacionado con el alcohol se objetiva los diferentes comportamientos de riesgos laborales. Conclusión: Las representaciones hechas por los participantes contribuyen directamente a las enfermeras realizan sus intervenciones de atención para esta población.

Descriptores: Enfermería; Salud laboral; Alcoholismo.

\section{INTRODUCTION}

Nowadays, alcoholism is configured as one of the biggest public health issues worldwide. It is estimated that this condition affects about $10 \%$ of the entire world population and $12.3 \%$ of the Brazilian population. ${ }^{1}$ Such percentages seem to justify the presence of a significant number of people with problems that are directly related to alcohol and alcoholism in the workplace, which is one of the main vectors of workrelated accidents. ${ }^{2}$

Concerning alcoholism as a public health issue in the workplace, it is the third leading cause of death in the world, behind cancer and heart disease alone. It is also estimated to be the third leading cause of absenteeism, and today it is the most frequent cause of precarious retirees and occupational accidents, and the eighth cause of granting sickness benefits by the Brazilian social security. Spending on direct and indirect damages resulting from alcohol abuse is also among the most significant in the health area. ${ }^{3}$

Work has a fundamental role in the lives of individuals, contributes to the formation of their identity, allowing the subjects to participate in the effectiveness and construction of their lives in society. Nevertheless, when the worker adds the consumption of alcoholic drinks in this relationship, the health and disease process in the work universe can be unbalanced. ${ }^{4}$

The worker on the effect of alcoholic drinks develops diminished attention to his activities, reduced peripheral vision, the false perception of the speed at which a vehicle drives, euphoria, and difficulty in discerning different luminosities spatially, in addition to decreased work production.,

For this reason, the abusive consumption of alcohol in the workplace allows workers to demarcate social domains and to build different realities around certain norms in force in the work environment that lead to the maintenance of occupational health, such as the use of personal protective equipment, conducting periodic examinations and preventing risky behaviors for the development of occupational accidents.?

Currently, discussions at the national and international levels have been developed to better understand the behavior of the subjects in regard to the alcoholic drinks' consumption.
In such discussions, points are highlighted that unfold as challenging to the public health sphere, such as: coping with the family, alcohol consumption among adolescents and women, and violence. ${ }^{4,6}$ Nonetheless, the point subscribed to between these discussions, and which is little explored in national and international literature, is the use of alcohol in the workplace.

The interest in this topic came from the involvement of one of the researchers, as an occupational nurse, where he assisted workers who experienced the effects of alcoholic drinks in their workplace, thus raising the need to know the representation of the drink for these subjects. So, the following question was formulated: What representations do workers have vis-à-vis alcoholic beverages? And, what is the relationship of such representations to their health promotion?

The knowledge produced by this study aims to contribute to future research on the topic and to assist nurses in visualizing the characteristics of the effects of alcoholic beverages on workers, thus minimizing doubts regarding the maintenance and prevention of possible occupational hazards.

Bearing the aforesaid in mind, social representations help us to clarify the phenomena of the subjects' consensual universe, as well as their practices concerning them. Consequently, social representations apply to this study that proposes to grasp the workers' common-sense knowledge about alcoholic drinks in the workplace. ${ }^{8}$ Hence, this study meant to identify and analyze the social representations of brewery workers concerning labor and the effects of alcohol on this relationship.

\section{METHODS}

It is a descriptive study with a qualitative approach that was performed based on the theory of social representations. Such theory has provided the knowledge to obtain indications on the way of thinking and acting in respect to alcoholic beverages, thus seeking to understand the relationship established by the population studied with this consensual act, as well as its influence on values, attitudes, opinions and behaviors. ${ }^{8}$

Data collection took place from April to May 2011, at the occupational medicine outpatient clinic of a company in the Pará State. As a criterion for participating in the research, the participant must be adult men, over 18 years old who provide direct services in the production company and who either do or did consume alcoholic beverages. There were obtained a total of 30 workers.

Two instruments were used, as follows: 1) a questionnaire of closed questions that aimed to identify the participants' profile; and, 2) a questionnaire in which the technique of free association of words was used, which consists of presenting an inducing word to the individuals (corresponding to the represented object) and ask them to produce any words, expressions or adjectives that come to mind from it. The word inducer was alcoholic drink in the workplace, and participants were asked to comment on that term. 
The data obtained were transcribed and analyzed using the content analysis technique that can be understood as the expression most commonly used to represent the treatment of data from a qualitative research through thematic analysis. ${ }^{9}$ This analysis is made by following the component structure 6 fundamental steps: 1) Familiarization with the data, which occurs through data transcription (if necessary), active reading of the data and annotation of initial ideas; 2) Code generation, which occurs through the systematic coding of relevant data; 3) Search for themes, in which there is a grouping of codes to transform them into potential themes; 4) Continuous review of the themes, as new ones are elaborated, generating a thematic "map" of analysis; 5) Definition of the themes, through the ongoing analysis aiming to improve the specifics of each theme; 6) Production of the report through an explanatory interpretation. ${ }^{9}$

Then, each story was translated into an elaborate discourse that, in short, is believed to express the social representations of workers concerning alcoholic drink in the workplace.

All stages of this study were carried out with the approval of the study scenario and the Research Ethics Committee from the Center for Biological and Health Sciences of the Universidade Estadual do Pará, under the protocol No. 0006.0.321.000-11, following all the precepts of the National Health Council through the Resolution No. 466/12 that regulates research involving human beings. All participants agreed to participate in the research, signing the Free and Informed Consent Form.

\section{RESULTS}

All the study subjects were male, within the age group from 20 to 50 years old, with complete high school education, with an income of up to two minimum wages, 17 of the participants were Catholics, 10 Evangelicals, and 3 Spiritists, all consumers of alcoholic beverages, residing in the Belém city, Pará State, and with more than one year of employment in the institution.

When alcoholic drinks are inserted in the worker's daily life, there is a loss of total or partial identity and the control of their movements at the time of drunkenness, so the risk for accidents at work increases significantly in this state, a fact that is correlated in the expressive statements of nineteen subjects.

"When it comes to drinking, I just drink, and when it comes to working, I just work, because it is harmful because it takes the person out of mind and leads to an accident, any lack of attention that the drink takes the worker to risk, sometimes that risk can lead to an accident and even death" (participant 2)

"Alcoholism is fun, different from work, which is a serious thing, so if you work with alcohol, the person ends up not working very well, because alcohol hampers things, disrupts the rules and routines, the person does not control himself and puts everything you do at-risk" (participant 13)
"Either one or the other, because the job requires the mind to be in perfect condition and alcohol does just the opposite, it only hinders development, it causes slowness of thought, leaves the eyes blurred and leads the person to risk accidents". (participant 14)

According to the speech made by six workers, when the worker ingests alcoholic beverages, he is a potential being emboldened with risky behavior for the development of mutilations within the workplace.

"The person loses responsibility and leads to an accident at work, for instance, there is this boxer machine, if the one vacillates, the machine pulls the arm and cut the head off. I think it is one of the worst things, so what shouldn't happen to a worker is to mix drinking with working" (participant 5)

"Naturally, there is already a risk of an accident, imagine if you consume alcohol, it becomes more dangerous because there is machinery that mutilates the hand and the body and if you are not careful it can cause death" (participant 8)

When alcoholism is present among workers, the time control, space and attitudes are increasingly at the mercy of self-control, the inexorable effects of alcoholic drinks on the central nervous system dictate the actions taken by men, reducing the criteria responsibility and health, as represented in the cases of sixteen workers exemplified below.

"Alcohol and work don't go together, I already missed work a lot because of that, because I couldn't stand up, but I never did it again, nowadays, I try not to drink because I know that this way I produce much more for the company, I prevent myself from causing an accident and work better because my family depends on me" (participant 10)

"Once I drank and came to work, and I realized that it's the worst thing I've ever done, I put my colleagues' lives at risk, I even had an accident and I was in danger of being fired. I do not advise anyone to come drunk for work, as it does not work, alcohol puts everything at risk, dreams, family, everything" (participant 21)

\section{DISCUSSION}

Concerning the effects of the association of alcoholic drinks and work, the representational universe disseminated by workers was inundated with concepts and symbols that, when interpreted, expressed what we believe to be the central core of the speeches. Such expressions were present through the representations of the association of the words that referred to the alcoholic drinks for the workers, it takes the person out of himself, takes a risk, and embarrasses the things that they do. Therefore, alcoholic drinks present in 
the workplace can cause damage, damage anchored in the participants' statements as being of extreme risk to both health and life.

Another point highlighted by workers in the alcohol/work relationship was the break in the balance of the health-disease process experienced by some participants, where sometimes the worker had to abstain from his responsibilities and his health towards his work because he was under the effects psychotropic effects triggered by alcoholic beverages. Such episodes were objectified in their thoughts when referring to experiences already lived in their daily lives with professional colleagues, which served as a warning for the non-reproduction of the association of the act of working under the effect of alcohol.

Supported by the context described by the participants, studies carried out in Canada report that the excessive consumption of alcoholic drinks affects individuals, companies, and societies as a whole, and this association is harmful for the development of health in these environments. ${ }^{10}$

A few studies address the simultaneous influences of work, the conditions in which it occurs, and mainly the factors that motivate workers to become potential consumers of alcoholic drinks outside this environment. As an example we have socio-cultural influences, which are the personal characteristics of each individual and their group where they share information. ${ }^{11}$ For this reason workers under the effects of alcoholic drinks tend to communicate, try to make familiar what is unfamiliar, try to implement their actions concerning drinking, introjecting their culture, and their comprehension about it.

Social representations are cognitive and behavioral rearrangements of objects and socially valued phenomena in the light of the subjects' worldview, the information that circulates in their environment, and the social position they occupy concerning the object, which in this study was represented by alcoholic drinks. Thus, each worker suffers the influence of his environment for alcoholic consumption, being one of the conditions for the production of social representations, the fact of being dependent on this environment. ${ }^{12}$

Through social representations, it is possible to explain how workers see, feel, and guide their actions under the effect of alcoholic drinks experienced by social groups in their workplace. It is noteworthy that the social knowledge found in the speeches of the participants is not an evolution from lay to scientific knowledge, as if there were a hierarchy between them, but a field mediated by language where they coexist and are structured, allowing the incorporation of knowledge and practices that anchor the way of dealing with novelty in a society, in this case, of alcoholic beverages in the workplace. ${ }^{13}$

This process shows the worker's ability to assimilate and produce his consensual knowledge in reified, but, from the perspective of social representations, this knowledge will only be socially represented when the shared experiences of human practices and actions are applied, ${ }^{14}$ in other words, when the worker puts his acquired knowledge into practice in his employment relationships.
The registered nurse in this context occupies a privileged space as "holder of knowledge", as he/she presents a discourse marked by the biomedical scientism of the academy focus on the other person, focused on the other's health, in other words, the worker. Such status deserves to be highlighted in this study, as it is understood that within the context of occupational health, the nurse is one of the communicators of information, anchored in scientific studies and experiments, which assist workers in the creation and circulation of social representations concerning alcoholic drinks, thus preventing them from possible exposure to occupational hazards and health problems. ${ }^{15}$

\section{FINAL CONSIDERATIONS}

Herein, it was possible to know the representations of workers about the consumption of alcoholic drinks and their relationship with their work activity. Alcoholic beverages were responsible for triggering moments of euphoria, lack of concentration and escape from reality, and their relationship with work was addressed as negative, which was trigger for occupational hazards.

Such representations are justified in the experiences lived by the group, and socialized through the language between them, a fact that allowed them to express their comprehension about the effects of drinking in the workplace and guided them to form their representations.

Here, it can be inferred that identifying how workers represent the relationship of alcoholism in the workplace through their social representations, directly contributes to nurses to provide care interventions. Considering the aforesaid, social representations allow the professional to enter the workers' universe, thus accessing the center of cultural and social influences that support their behavior in the real world, in other words, in their workplace.

This work presented as a limiting factor the difficulty of getting the workers to participate. It was due to the fear of being identified by their superiors, since consuming alcohol was the inclusion criteria of this study. Even though we are aware of the confidentiality that the research ethics recommends, we still found resistance. Therefore, few representations were evidenced because there are still questions to be clarified, such as: Although people are aware of the consequences that the alcoholic drinks have in the workplace, why there are still many workers who do drink it? Hence, there is a need to encourage future studies for further understanding on this matter.

\section{REFERENCES}

1. Sousa LGS. Menandro MCS. Menandro PRM. Alcoolismo, suas causas e tratamento nas Representações Sociais de profissionais de Saúde da Familia. Rev. Physis (R. Janeiro).2015:25(4):1335-1360

2. Sureca X, Villalbi JR, Espelt A, Franco M. Living under the influence: Normalisation of alcohol consumption in our cities. Gac Sanit.2017; 31(1):66-68.

3. Fernandes MA. Percepção dos enfermeiros sobre o significado dos cuidados paliativos em pacientes com câncer terminal. Ciência \& Saúde Coletiva. 2013;18(9): 2589- 2596 
4. Lavigne AM, Wood MD, Janssen T, Wires RW.Implicit and exliit alcohol cognitions: the moderating effect of executive functions. Alcohol Alcohol. 2017;52(2):256-262.

5. Wiers CE, Gladwing TE, Ludwig VU, Gropper S, Stuke H, Gawror $\mathrm{CK}$ et al. Comparing there cognitive biases for alcohol cue in alcohol dependence. Alcohol alcohol. 2017;52(2):242-248.

6. Ferreira MA. Teoria das Representações Sociais e Contribuições para as Pesquisas do Cuidado em Saúde e de Enfermagem. Esc. Anna Nery.2016;20(2):58-70

7. Silva, SED et al. Representações sociais sobre a doença de mulheres acometidas do câncer cervico-uterino. Rev. pesqui. cuid. fundam. (Online):2016;8(1): 3667-3678

8. Almeida AMO, Santos MFS, Trindade ZA. Teoria das representações sociais, 50 anos, Technopolitik Editora, Ybook, pdf, 2 edição. 2014.

9. Clarkc V, Braun V. Theaching thematic analysis: Over -coming challenges and developing strategies for effective learnig. The psychologist.2013; 26(2):120-123

10. Silva SED, Padilha MI. História de vida e representações sociais sobre o alcoolismo. Novas Edições Acadêmicas. 2016

11. Silva SED, Padilha MI, Araujo JS. A interação do adolescente com o familiar alcoolista e sua influência para adicção do alcoolismo. Rev Enf. UFPe on-line.2014: 8(1):59-69

12. Araújo JS, Silva EDS, Conçeição VM, Santana ME, Souza FS A bebida alcoólica no contexto laboral: um diálogo mediado pelas representações sociais. Revista Tempus Actas de Saúde Coletiva. 2012; 06 (2): 217-233.

13. Freitas NO, Souza JC, Araújo EC. As representações sociais. Revista de enfermagem da UFPE on-line: 2015;9(7):16-30

14. Sena ELS, Carvalho PAL, Lauton MAR, Andrade LM, Jesus IS Vivência de uma pessoa com câncer em estágio avançado: um olhar segundo a perspectiva de Merleau-Ponty. REME:2013; 17(3):635-643

15. Triviños ANS. Introdução à pesquisa em ciências sociais, a pesquisa qualitativa em educação, são Paulo, editora atlas; 2015

Received in: 28/02/2017

Required revisions: Did not have

Approved in: 10/03/2017

Published in: 01/08/2020

Corresponding author

Silvio Éder Dias da Silva

Address: Passagem Boaventura da Silva, 129, Fátima

Belém/PA, Brazil

Zip code: $66.060-470$

Email addreess: silvioeder2003@yahoo.com.br

Telephone number: +55 (91) 98158-0748

Disclosure: The authors claim to have no conflict of interest. 